\title{
Handovers and Debussy
}

\section{P Stevens}

When I started to study the piano at the age of eight, I would labour over my exercises and pieces, one note at a time. As I learned to read music, there was always a sense of accomplishment when the played notes seemed to reflect correctly the musical score in front of me. I don't recall anyone ever calling me a musician, certainly not my first teacher. Getting the individual notes right and in correct sequence was a long way from making music. For me it was all about the notes. Claude Debussy is said to have clarified this issue that generally eludes most novice musicians, when he said, "Music is not just about the notes. Rather it is created by the spaces between the notes."

Healthcare steadily becomes more complex-more chronically ill people who live longer, and sicker patients who require more powerful medicines and riskier procedures. Randomised controlled trials indicate the drugs and procedures that work best for many diseases. Junior doctors (resident trainees) learn these parts quickly and effectively. As important as this knowledge is, there is increasing recognition that the value of learning these components well is just part of good healthcare. Successful healthcare requires attention to effective connectivity between each and every componentthe spaces between the notes.

\section{TRAINEE COMPETENCE AND HANDOVERS}

One area where the spaces are increasingly of concern is handovers or transfers between health professionals, particularly doctors in training. This has long been an essential part of care processes in teaching hospitals, ${ }^{1}$ so why the increased attention now? Reduced duty hours for health professionals, at the same time that patients are sicker and treatments are more complex, is part of the explanation. And as duty hours become more restricted around the world, the number of handovers among health professionals who care for a particular patient inevitably

Correspondence to: Dr D P Stevens, Adjunct Professor and Director, Quality Literature Program, Dartmouth Institute for Health Policy and Clinical Care, 30 Lafayette Street, Lebanon, NH 03766 USA; David.P.Stevens@ Dartmouth.Edu increases-more parts that have to work effectively together.

The Accreditation Council of Graduate Medical Education (ACGME), the public agency charged with accreditation of postgraduate training in the USA, has called for attention to just six general competencies for the 100000 resident trainees in the over 7000 resident training programmes in the USA. The six ACGME general competencies are patient care, medical knowledge, professionalism, communication, practice-based learning and improvement, and systems knowledge. ${ }^{2}$ Although medical educators have traditionally focused on the competencies that describe the individual parts in medical education-for example, medical knowledge or patient care-the ACGME has put equal emphasis on the competencies that characterise the interactions between the components. Communication, professionalism, and systems knowledge constitute fully half of the ACGME general competencies.

\section{A WELL-DEFINED PROBLEM THAT CALLS OUT FOR A SOLUTION}

Borowitz and colleagues (page 6) demonstrate again in this issue of Quality and Safety in Health Care the problems that develop in healthcare quality and patient safety when handovers are left to chance in teaching hospitals. ${ }^{3}$ They report that over a quarter of untoward events in their teaching hospital might have been anticipated, and perhaps better managed, with more effective sign-out information between shifts of doctors. Thanks to this report, as well as others that document similar risks associated with handovers, ${ }^{146}$ sufficient evidence exists that poor communication across shifts of trainee doctors is a source of unsafe care.

It is time to move to solutions. This calls for medical educators, particularly those with responsibility for junior doctors' education, to develop strategies and standards that no longer leave effective handovers to chance. The resident trainees who were the study subjects in the Borowitz report recommended a minimum of three components:

- sign-out information is up to date and timely;
- the care plan is communicated so that changes that might be required by emergent changes in the patient's condition are anchored in a clearly defined context;

- anticipated potential problems are communicated with recommendations for contingencies. ${ }^{3}$

Arora and colleagues (page 11) bring the reader back to the ACGME competencies in a proposal that also appears in this issue. ${ }^{7}$ Their recommendations describe a theoretic base for handovers that addresses both economic burden and patient safety. They emphasise communication, and they also call attention to professionalism. Such an emphasis suggests three additional opportunities for improvement in an increasingly discontinuous care environment ${ }^{`}$ :

- bringing the patient into the process;

- professional responsibility-from a concept of "not my patient" to "every patient is my patient";

- exploitation of the broader health professions team for better handovers.

\section{LEARNING FROM OTHER HIGH-RISK ORGANISATIONS}

Fortunately, health professionals are not alone when it comes to the challenge of handovers. Patterson, in a commentary in this issue (page 4), offers a number of hard-won lessons from non-healthcare high-risk organisations (HROs) such as nuclear submarines, space missions and nuclear power plants. ${ }^{8}$ The application of human factors research to handovers in HROs provides many such lessons, including the importance of attention to complexity and context, as well as an emphasis on parsimony, flexibility and anticipation of problems. ${ }^{8}$ Be warned that many in healthcare may find these lessons counterintuitive. Nevertheless, given the currently well-documented contribution to insufficient healthcare quality and patient safety of inadequate handovers, educators should consider testing these lessons before discarding the rich experience from which others have learned.

When I was a young piano student, my teacher knew when to shift my learning beyond slavishly reading the correct notes to a focus on making music. In so doing, she was not ignoring the notes, but adding the richer contribution of the spaces between the notes. It is time that healthcare in general and medical education in particular, focus attention on the 
opportunities for healthcare quality and safer patient care that are provided by systematically addressing handovers in teaching settings.

Competing interests: None.

Qual Saf Health Care 2008;17:2-3.

doi:10.1136/qshc.2007.025916

\section{REFERENCES}

1. Petersen LA, Brennan TA, O'Neil AC, et al. Does housestaff discontinuity of care increase the risk for preventable adverse events? Ann Intern Med 1994;121:866-72.

2. Leach DC. Changing education to improve patient care. Oual Saf Health Care 2001:10:54-8.

3. Borowitz SM, Waggoner-Fountain LA, Bass EJ, et al. Adequacy of information transferred at resident sign-out (inhospital handover of care): a prospective survey. Qual Saf Health Care 2008;17:6-10.

4. Sutcliffe KM, Lewton E, Rosenthal MM. Communication failures: an insidious contributor to medical mishaps. Acad Med 2004;79:186-94.

5. Arora V, Johnson J, Lovinger D, et al. Communication failures in patient sign-out and suggestions for improvement: a critical incident analysis. Oual Saf Health Care 2005;14:401-7.

6. Solet DJ, Norvell JM, Rutan GH, et al. Lost in translation: challenges and opportunities in physician-to-physician communication during patient handoffs. Acad Med 2005;80:1094-9.

7. Arora VM, Johnson JK, Meltzer DO, et al. A theoretical framework and competency-based approach to improving handoffs. Qual Saf Health Care 2008;17:11-14.

8. Patterson ES. Structuring flexibility: the potential good, bad and ugly in standardisation of handovers. Qual Saf Health Care 2008;17:4-5.

\section{Committee on Publication Ethics (COPE) - Seminar 2008}

\subsection{0am-4.30pm Friday 4 April 2008, Woburn House, London, UK}

This year's seminar will focus on three key topics: (1) How does patient privacy legislation affect an editor's ability to publish? (2) What is publication? - the changing definitions of publication. (3) COPE's new Best Practice Guidelines. There will also be a short demonstration of an anti-plagiarism system as it is working in a publishing house.

Invited speakers will discuss legislation on privacy and data protection that editors need to be aware of; how editors should respond to more and more data being available online prior to formal peer-reviewed publication; and what happens to a publication after it appears in print.

The newly designed COPE website will be demonstrated, and there will be interactive workshops on common ethical and editorial dilemmas.

Editors, authors and all those interested in improving the standard of publication ethics are welcome.

The seminar will include invited talks:

- A Pandora's box of tissues-legislation in relation to tissues and cells

- The promise and perils of patient privacy

- Pre-publication or duplicate publication? How to decide

- What really happens to a publication after it appears in print

- Screening for plagiarism: the CrossCheck initiative

In addition:

- Discussion of COPE's new Best Practice Guidelines with experiences from journals who have piloted the audit

- COPE's new website unveiled

- Interactive workshops on the key topics of the seminar.

- Opportunities to network with other editors and share your experiences and challenges

The seminar is free for COPE members and $£ 50.00$ for non-members. Numbers are limited and early booking is advisable. For registration or more information please contact the COPE Administrator at cope@bmjgroup.com or call 020-7383-6602.

For more information on COPE visit www.publicationethics.org.uk/ 